\title{
After deindustrialisation: changing urban economy in the Danube valley region
}

\section{Claudia Popescu*}

Academy of Economic Studies Bucharest E Institute of Geography Romanian Academy, Romania

The paper is aiming to discuss the role of deindustrialization in generating socio-economic dislocation at regional level. The change of industry along the way from the centrallyplanned to market oriented economy, while redefining the spatial patterns of growth and decline, has combined with emergent forms of social and economic inequality. The specific aims of the paper are twofold. First, having the privilege of a two and a half-decade long perspective, the paper looks back at the period of deindustrialization, pinpointing the successive waves of employment decline in the wider context of the extensive process of economic restructuring. Second, using methods of spatial analysis, the paper examines the new distribution pattern of industrial change in the Danube region, specifying in empirical terms the relation with evolutionary trends and regional specialization. The findings pinpoint at the consequences of the far-reaching deindustrialization process on the regional economic base of the Danube towns.

Key Words: deindustrialization, urban economy, regional specialization, Danube Valley Region.

Article Info: Received: June 3, 2016; Revised: September 24, 2016; Accepted: October 15, 2016; Online: November 30, 2016.

\section{Introduction}

Deindustrialization has expanded to former communist countries since the early 1990s, causing a period of socio-economic dislocation, materialized in rationalization of production, plant closings and rising unemployment rate. Restructuring the economy was initially accomplished by shrinking the oversized socialist industrial sector, leading to a new cycle of economic transformation that changed mainly the urban economies (Popescu, 2014). The transition

\footnotetext{
* Correspondence address

Address: Academy of Economic Studies Bucharest. Faculty of Commerce - Department of Tourism and Geography 41 Dacia Blvd., zip code 010404, Romania.

Phone: +403191990/ext 378 | Email: cldpopescu@yahoo.com
} 
to the market economy and trade reorientation, as a consequence of COMECOM dissolution, have resulted in a structural change, mainly industrial restructuring and labor reallocation across sectors and regions. In the 1990s, Romanian industry has experienced considerable decline in output and employment.

The South of the country has a strong agricultural legacy and a long standing economic and social underdevelopment. With few exceptions, industrialization came late to the Danube region, hence it was only after the 1970s that significant industrial investments targeted the Danube towns. There were two reasons justifying this choice: firstly, the tendency for a balanced and uniform development of the industry was emphasized by the end of the socialist period; secondly, the Romanian economy was increasingly dependent on imported energy and mineral resources, thus the Danube riparian and Black Sea coast location of industry came to be a basic principle of the economic development policy. However, the effort to develop poorer regions had only short-term effects: developing a modest industrial base has served to reduce underemployment and the excessive interregional migration of rural population. Anyway, the traditional agricultural belt of the Danube towns was turned into a manufacturing belt. In the late 1980s, one third of the Danube cities hosted steel companies as a result of the overemphasis on heavy industry pursued by the economic policy.

The paper is aiming to discuss the role of deindustrialization in generating socio-economic dislocation at regional level. The change of industry along the way from the centrally-planned to market oriented economy, while redefining the spatial patterns of growth and decline, has combined with emergent forms of social and economic inequality. The specific aims of the paper are twofold. First, having the privilege of a two and a half-decade long perspective, the paper looks back at the period of deindustrialization, pinpointing the successive waves of employment decline in the wider context of the extensive process of economic restructuring. Second, using methods of spatial analysis, the paper examines the new distribution pattern of industrial change in the Danube region, specifying in empirical terms the relation with evolutionary trends and regional specialization.

The paper begins by reviewing the link between deindustrialization and the overall economic restructuring, drawing attention on the shifts of employment across the economic sectors. It follows then a closer examination of the successive rounds of investment and disinvestment and the deep implications over deindustrialization and economic cycles since the early 1990s. Regional relocation of industries creates a pattern of uneven growth which stays at the core of understanding the new geography of manufacturing in the Danube Region. Finally, the paper attempts to capture the consequences of the far-reaching deindustrialization process on the regional economic base.

\section{Deindustrialization and the economic restructuring in the Danube Region}

The Danube Region with its agricultural potential and declining industry was structurally affected by inter-sectoral employment shifts which gave birth to a 
new economic specialization. The region was subject to similar changes with those at the national level. Restructuring the economy was initially accomplished by shrinking the oversized socialist industrial sector, leading to a counterproductive expansion of the agricultural sector that played the role of a buffer (Maniu et al. 2001). During the 1990s, the employment share of the industry sector in Romania has contracted by $8 \%$. This loss was matched by an increase in the employment share of the agricultural sector, which had a share of $40 \%$ in national employment in 1999 (Traistaru and Wolff 2003). While the agricultural sector remained at 3.4 million employed, the industrial sector lost more than 1 million workers, with the number of employed persons falling from 3.3 to 2 million during the 1990s (idem). Broadly speaking, manufacturing has been following a path of a long-run decline in employment, while services have been experiencing a slow growth, but this has been far from a „smooth” evolutionary transition. The two sectors are embroiled in a form of combined and cumulative restructuring, with profound implications both for socio-economic sustainability and for the distribution of jobs and incomes. The other main sector of the economy, agriculture became dominated by self-employment and low revenues stemming largely from subsistence farming. In comparison with other former socialist countries, Romania was characterized by a huge aggregate structural change, especially a process of deindustrialization and consequently a process of re-agrarization (Traistaru and Wolff, 2003), which basically reversed the shares of the two sectors in the total employment during the first decade of transition (industry $-37.9 \%$ in 1990 and $23.5 \%$ in 2001 ; agriculture $-28.2 \%$ in 1990 and $40.4 \%$ in 2001) (Pavelescu 2003). Labor resources have moved from industry to agriculture rather unusually for a European country in the process of postcommunist transformation, with services employing a largely stagnant share of all employed. The agricultural sector and rural areas have acted as a kind of buffer, absorbing people who have lost jobs in industry and have not been able to find employment in the slowly developing service sector.

The variance of regional employment growth was driven almost entirely by region-specific factors, while industry mix and regional competitiveness factors played only a minor role in explaining regional employment dynamics (Traistaru and Wolff 2003). Highly specialized regions are more vulnerable to asymmetric shocks, since industry shocks may become region-specific shocks as, for instance, in the case of former mining regions. The level of industrialization at the beginning of the transition period, in 1992, plays a significant role in explaining the different paths of evolution taken by regional economies. In stronger industrialized regional economies, the manufacturing loss has largely exceeded the total employment loss showing a better capacity of services to expand and absorb the workforce released by the industrial sector. A closely related factor is the large-scale urban economies that enhanced the economic potential of regions to grow. The weaker industrialized economies, on the contrary, seemed to suffer the most due to their limited capacity to attract growing economic activities. Here, the ratio between the manufacturing and total employment loss was reversed and regional economies were subject to long term decline. The positive correlation between the initial level of industrialization and the path of transition is a legacy of the socialist era when the progress to economic development was almost entirely based on manufacturing growth. 
The onset of deindustrialization in the early 1990s represented the end of what had been the dominant mode of urban-economic development for the most of the second half of the 20th century. In the same time, it marked the beginning of a painful shift toward a new pattern of unequal and unstable growth. During the 2000s, the manufacturing employment contraction was less important, since the growth of export-oriented industries along with increasing entrepreneurship and foreign direct investments (FDI) in manufacturing have contributed to a robust economic growth until the onset of the crisis in 2008. Huge disinvestments in industry have caused a sharp decline of employment for the next three years, followed by the recent rebound of the economy and moderate industrialization. Having compared the trends of the manufacturing employment along the whole period of 1992 to 2015 and at three distinctive scales, national, the Danube Region and the rest of the regions, interesting characteristics could be outlined. There is a strong dissimilarity of the evolution paths taken by the manufacturing employment at national and the rest of the regions on one side and the Danube Region on the other side. During the time of recession in the 1990s and the crisis in the late 2000s, the Danube Region has lost less manufacturing employment in the first period but more in the second period than the national and the rest of the regions. The initial lower industrialization level explains the better performance of the region than the average in the 1990s, whereas the stronger loss of manufacturing employment during the crisis is due to structural factors related to the types of industries located in the region in the 2000s. Although with a succession of positive evolutions in terms of manufacturing employment, the region has attracted mainly low knowledgeintensive industries. The region without large and diverse agglomerations has found increasingly difficult to attract investment from multinational corporations wishing to export or to access wider market areas. Anyway, there are few exceptions in the region, ArcelorMittal in Galati and St. Gobain in Calarasi, and both develop resource-based activities. The cumulated structural disadvantages impeded the region to perform better in recent years (Figure. 1). All along the period of 1992-2015, the Danube Region has scored a $48.18 \%$ loss of manufacturing employment in comparison with $41.80 \%$ decrease at national level.

Any attempt to explain the evolution of spatial inequalities caused by deindustrialization has to be placed within the general context of Romania's transition to the market economy starting from the early 1990s. Although regional inequalities were relatively low before, they rapidly increased since the beginning of transition, as the political control of the economy was gradually replaced by market forces (Goschin et al., 2008). In other words, the role of the state as industrial owner and industrial location regulator has been substantially curtailed under the regime of liberalization and structural reforms. As a result, the state-owned industrial system has been gradually dismantled and the private SMEs scored a contribution of about $70 \%$ of the GDP in the dawn of the economic crisis (Isaic-Maniu 2008). Therefore, with the increasing dominance of private sector industrialization, industries tend to be more spatially concentrated in leading industrial regions, which cause higher levels of spatial inequality. The emerging spatial pattern of industrialization is led by investments made by the private sector which is demonstrably averse to lagging regions. Economic restructuring has had a significant negative impact upon mono-industrial 


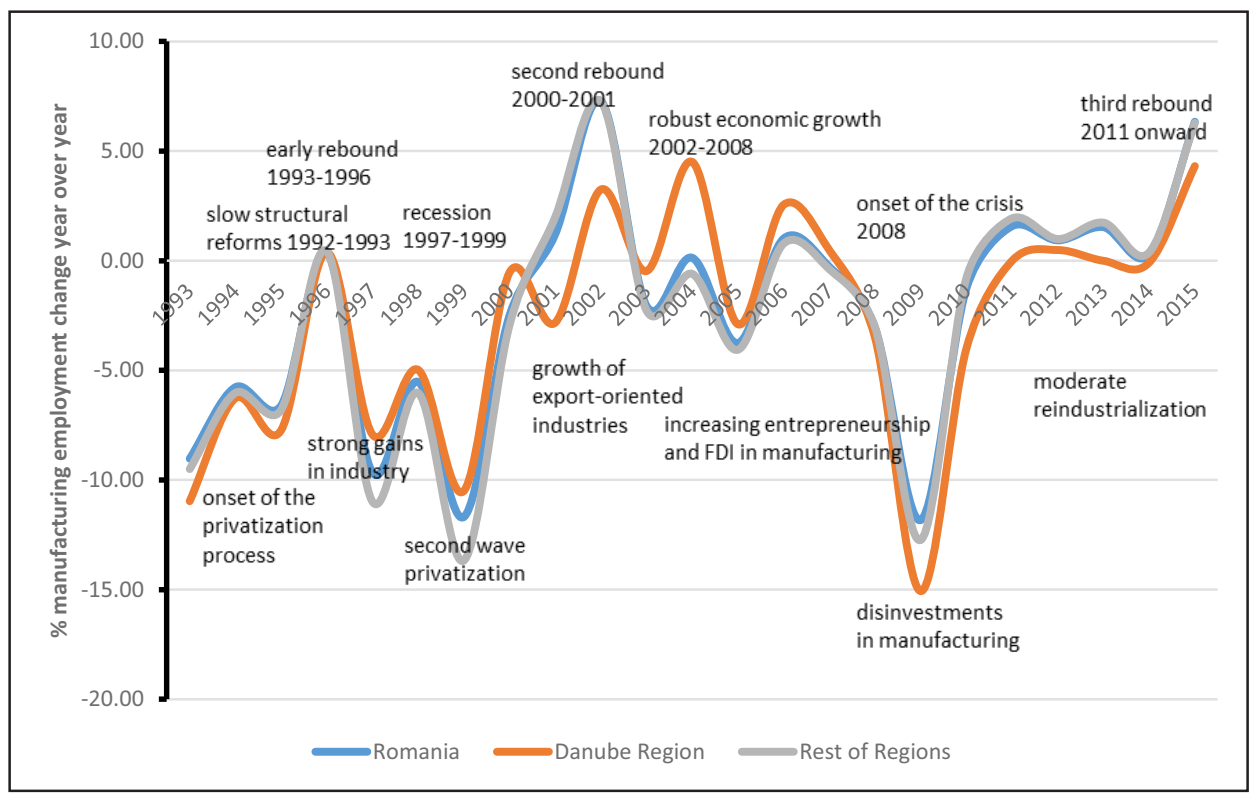

Figure 1. The manufacturing employment change at national and regional level, 1992-2015 Source: National Institute of Statistics

regions, thus deepening regional disparities (Goschin et al. 2008). Besides, rates of regional convergence are more rapid in periods of economic growth, while divergence is more typical during recessions.

Additionally, external factors have contributed to the growing regional divergence. Economic and trade integration with the European Union was likely to generate changes in the development trajectories of regions. On one side, above average developed regions are in progress if located westward or based on metropolitan economies or in decline if they are inward-oriented regions. On the other side, under average developed regions are in progress if placed at the border with non-EU regions or in decline if positioned in the southern periphery. The process of economic integration changed the reference market for firms producing in the country. Given transportation costs, trade liberalization shifted resources to regions with a better access to foreign markets, such as border regions and port-cities and the Danube Region appeared to be more favored.

Therefore, the economic integration into the $\mathrm{EU}$ has reduced the inward orientation of most of the manufacturing industries. In fact, during the 1990s, relocation processes within different manufacturing sectors, have been driven mainly by three factors: FDI, agglomeration of industry and the EU trade integration. The openness of economy to trade and foreign investments in early 1990 s, brought to a sudden end the decades of inward oriented policies of industrialization. The shift in the location of the manufacturing activities has involved a spatial decentralization of employment, as industry moved from autarky industry location centers, mainly internal regions, to a number of locations with a better access to the EU markets, thus changing the regional specialization. These macro-scale shifts might have triggered economic growth of the Danube Region as well, unless the poor connectivity and inefficient 
institutional framework of trans-border cooperation would have diminished the development opportunities of the region.

\section{Deindustrialization of the Danube towns}

The Danube towns are placed in a particular regional context. First, it is about their peripheral geographical location. Cities have always been defined by their centrality. They have for long been seen as a spatial symbol of central and centralizing forces, especially the cities of industrialization fed by uprooted rural populations. Situated along the Danube, towns show a strong peripherability which is assessed in both geographical and economic terms as there is a close correlation between location and economic performance (Dawson, 1992). The economic performance of peripheral cities is comparatively weak and very often constrained by underdeveloped economic structures, a dependence on relatively small regional and local markets and the absence of efficient communication links to the national „core” and other peripheral urban centers.

Second, it is about the agricultural legacy of the region and consequently the high level of rurality. The proximity to major cities, the capital city of Bucharest and some growing regional cities in the neighborhood, without being paralleled by communication infrastructure, has led to underdevelopment, out migration, poor human capital, low incomes, rising unemployment combined with "survival" self-employment, and eventually to poverty. Especially, rural poverty has moved from Moldova to South Muntenia and Oltenia (Sandu, 2011), across the former poverty is scattered in pockets, whereas the latter turns into a continuous poverty belt. Since rurality is closely associated with underdevelopment, the Danube towns are deprived of development opportunities due to the laggard socio-economic context of the region.

Third, it is about the scale of urbanization in the Danube Region. There are 28 towns of various demographic scales and economic power. With few exceptions, the most of them are small and medium-sized located within the urban economic areas of bigger cities outside the region. Three major urban economic centers exert gravitational pull over the Danube Region (Orase competitive, Remodelarea geografiei economice a Romaniei, 2013). The city of Craiova expands its economic influence area over small Danube towns such as Bechet, Dabuleni, Bailesti, and Calafat. The capital city of Bucharest engulfs the towns of Giurgiu, Oltenita and Calarasi, while the city of Constanta extends over Fetesti and Cernavoda area. In comparison with metropolitan or regional cities, which are linked together by organizational web of transnational corporations, their facilities, suppliers, and subcontractors, the peripheral cities are less connected to competitive economic networks. Strained by poor scale and urbanization economies, the Danube towns have been subject to disinvestments and rising unemployment which hinder their further socio-economic development.

Last but not the least, it is about the changing context of the urban development. Post-communist cities evolve within a profoundly different context from that existent prior to the 1990s. The emerging context of the post-communist city is defined by some basic characteristics - market based restructuring system, 
core vs. periphery, selective urban growth, declining and aging population, shrinking cities, chaotic suburbanization (Dumitrache et al., 2016). As a result, some urban regions performed significantly differently from the rest of the country - especially regions with strong metropolitan economies were growing slower after controlling their industry structure and initial specialization. The higher concentration of industries works for the stability of localized production systems and, subsequently for the enhancement of regional economic growth. Over a longer span of time, highly specialized urban regions were able to take advantage of their localization and urbanization economies and reduce their vulnerability to shocks. Assigned to play the role of the industrial core during the socialist times, these regions have not lost their initial advantage. Additionally, the under-industrialized urban regions, even though having largely replicated the trend of the national average, still remained very different from the benchmark distribution of industrial employment, suggesting that their underdevelopment comes equally from their inherited past and low resilience to economic shocks after the 1990s.

There are two groups of diverging regions recording the highest scores of disparity: the most and the least industrialized. Among the former group, there are regions with a solid industrial legacy and a level of economic development well above the average (Prahova, Arges, Sibiu, Cluj, Brasov). The latter group is made up of regions featuring the lowest shares of manufacturing employment in the total (Calarasi, Giurgiu, Ialomita, Teleorman, Botosani) and overall economic underdevelopment. It seems that in both cases, the „industrial trajectories" are essential in designing the road map in which an established direction guides more easily one way than another and overall reversals are difficult. In the first case, former industry concentrations, availability of reliable infrastructure to reduce transport costs and enhanced market access, regional amenities and economic diversity fuel localization economies. In the second case, the lack of this kind of incentives, all together with the inherited industrial underdevelopment, makes these regions deprived of agglomeration economies. Continuity rather than change stays at the core of the emerging spatial pattern of industrialization. On one hand, private investments in industry, either through the location strategy of multinationals or domestic entrepreneurship, search for competitive advantage of developed regions drawing on their urbanization economies and industrial diversity. On the other hand, lagging behind regions enter a „lock-in” stage of development unless alternative ways to promote regional development are found (for example, given their ruralized and agricultural character, the creation of agri-food supply chains would be a successful way-out).

Location shifts take place very slowly and the long time series data of 1992-2011 is necessary to appreciate the real changes in industrial relocation and regional specialization. Regional specialization and geographic concentration of industries are defined in relation to production structures. The subsequent spatial patterns are determined by the interaction between regional and industry characteristics. The reason for evaluating the interaction between regional and industry characteristics lies in the fact that firms, and industrial firms in particular, assess the same kind of production factors differently. Following this assumption, industries are over- or underrepresented in relation to the produc- 
tion factors endowment of regions. Industries tend to locate where their most important inputs are available (work force abundance for labor intensive industries or higher share of $\mathrm{R} \& \mathrm{D}$ employment for high-tech industries). Likewise, industries with higher economies of scale tend to concentrate in relatively central locations (Fujita et al. 1999; Midelfart-Knarvik 2000). Finally, larger regions have larger shares of manufacturing activity (Traistaru et al. 2002).

The Danube Region is made up of 12 counties located along the river, accounting for $28.5 \%$ of the total number of counties in the country. Nevertheless, their contribution to the national manufacturing employment is under-represented, having a declining share of $9.48 \%$ in 1992 and $7.20 \%$ in 2011 . Over the period, the region has almost halved the industrial employment with the biggest losses in Galati and Giurgiu and the smallest in Ialomita. The rest of the region has scored a 30 to $60 \%$ employment contraction in manufacturing. The share of the manufacturing companies in the region out of the national total has remained stable at $15-16 \%$ from the late 1990 s to 2014 , but it is not their relative value to be relevant to assess the economic performance of the region, more important is their sectoral breakdown reflecting the balance between low versus high knowledge-intensive activities. The Danube region, without large and diverse agglomerations, could hardly attract investments from innovative and growing firms searching to export or to access wider market areas. This liability is consistent with the declining contribution of the region to GDP creation. In the mid-1990s, the share of the twelve Danube counties in the national GDP was $21.94 \%$, whereas in early 2000 s the value dropped at $17.87 \%$, suggesting that the region has a significant gap in providing national wealth.

Hardest hit were the Danube towns which have lost considerable shares of manufacturing employment since the early 1990s (Figure 2 a,b,c). The scale of the urban deindustrialization in the region is shown by the sharply declining average share of industrial employment out of the total from almost half in 1992, to approximatively one third in 2002 and, finally, to a quarter in 2011. At the beginning of the economic restructuring, the region was made up of industrial towns specialized in heavy industries as a rule and a large number of agricultural or mixt towns. The Danube towns with above average share of industrial employment were characterized by large scale production units represented by shipyards (Oltenita, Giurgiu, Orsova), chemical industry (Turnu Magurele), tools and machine building (Braila, Bailesti), and metallurgical works (Galati). Below average share of industrial employment was particular to a more numerous group of Danube towns, usually small sized and traditionally specialized in agriculture (Corabia, Ianca, Segarcea, Harsova, Budesti, Insuratei, Dabuleni, Bechet). Anyway, in early 1990s industry was the largest employer and the onset of deindustrialization has considerably marked the urban economies of the region.

All along the first decade of the transition period, more than 100,000 industrial jobs have been lost. Many industrial firms have been closed down and in others the production has been largely rationalized. As a result, both the above and below average industrialized towns of the region have suffered radical changes of their economic base. Nevertheless, there was a significant shift of labor from the industrial sector to agriculture and services. The shift is 


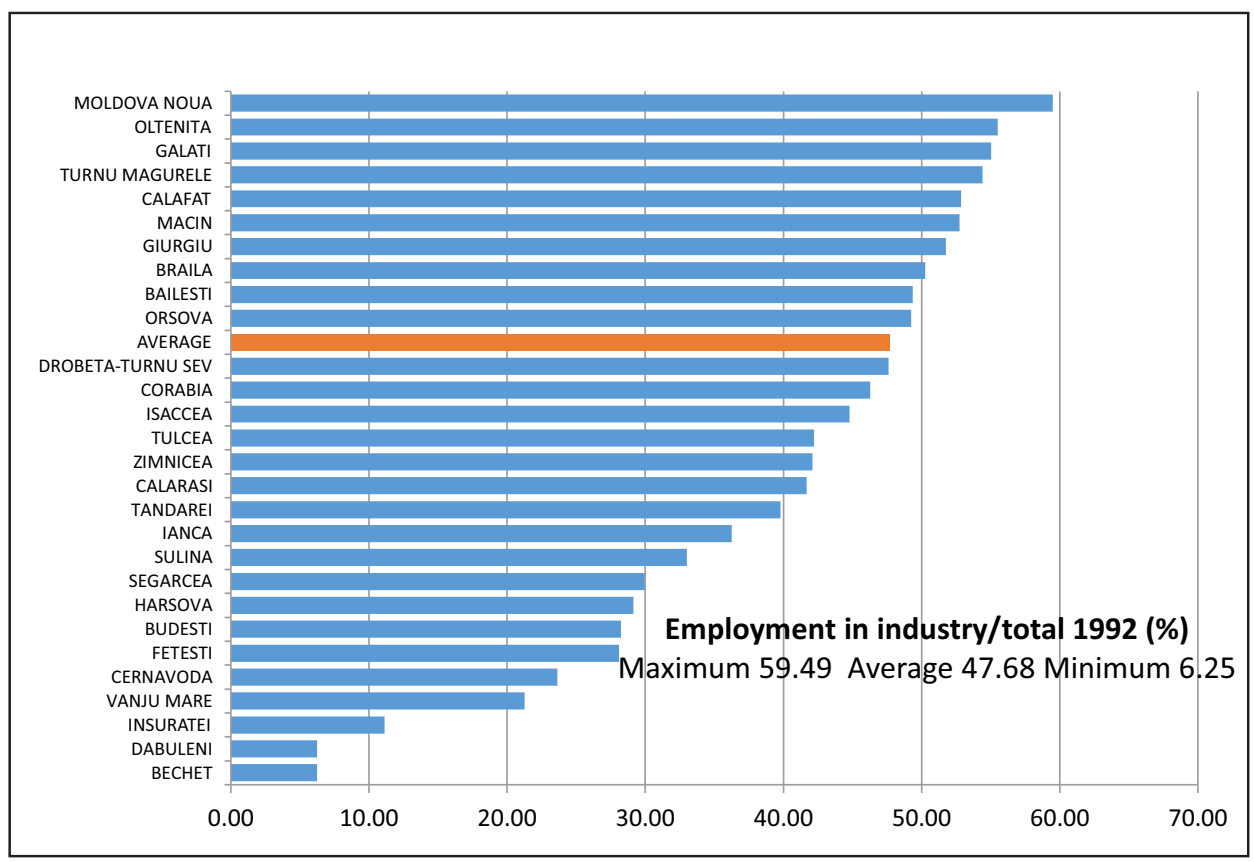

Figure 2. Deindustrialization of the Danube towns in 1992 (a)

Source: National Institute of Statistics

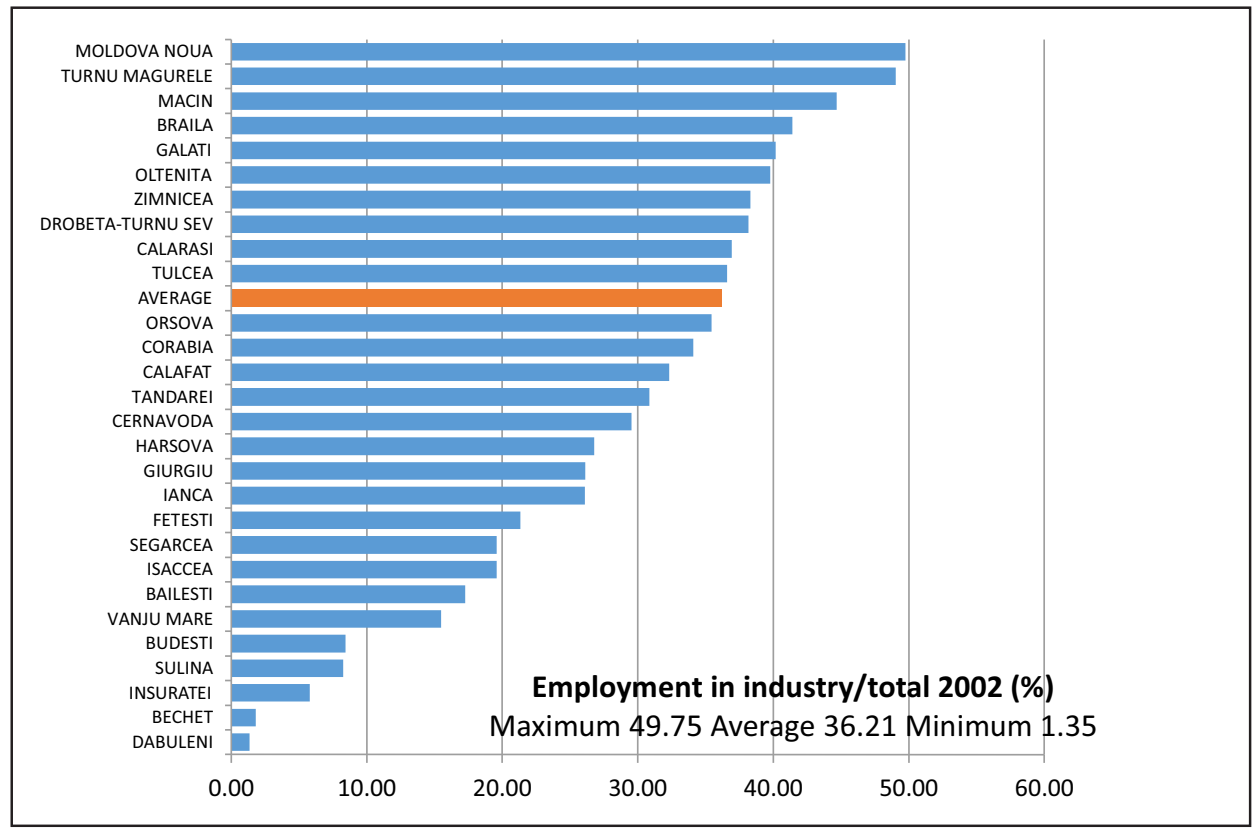

Figure 2. Deindustrialization of the Danube towns in 2002 (b)

Source: National Institute of Statistics

demonstrated by the less significant decline of the total employment of $18.52 \%$ in the 1992-2002 period in comparison with the industrial employment loss of $38.12 \%$ in the same period, meaning that a part of the layed off workforce from 


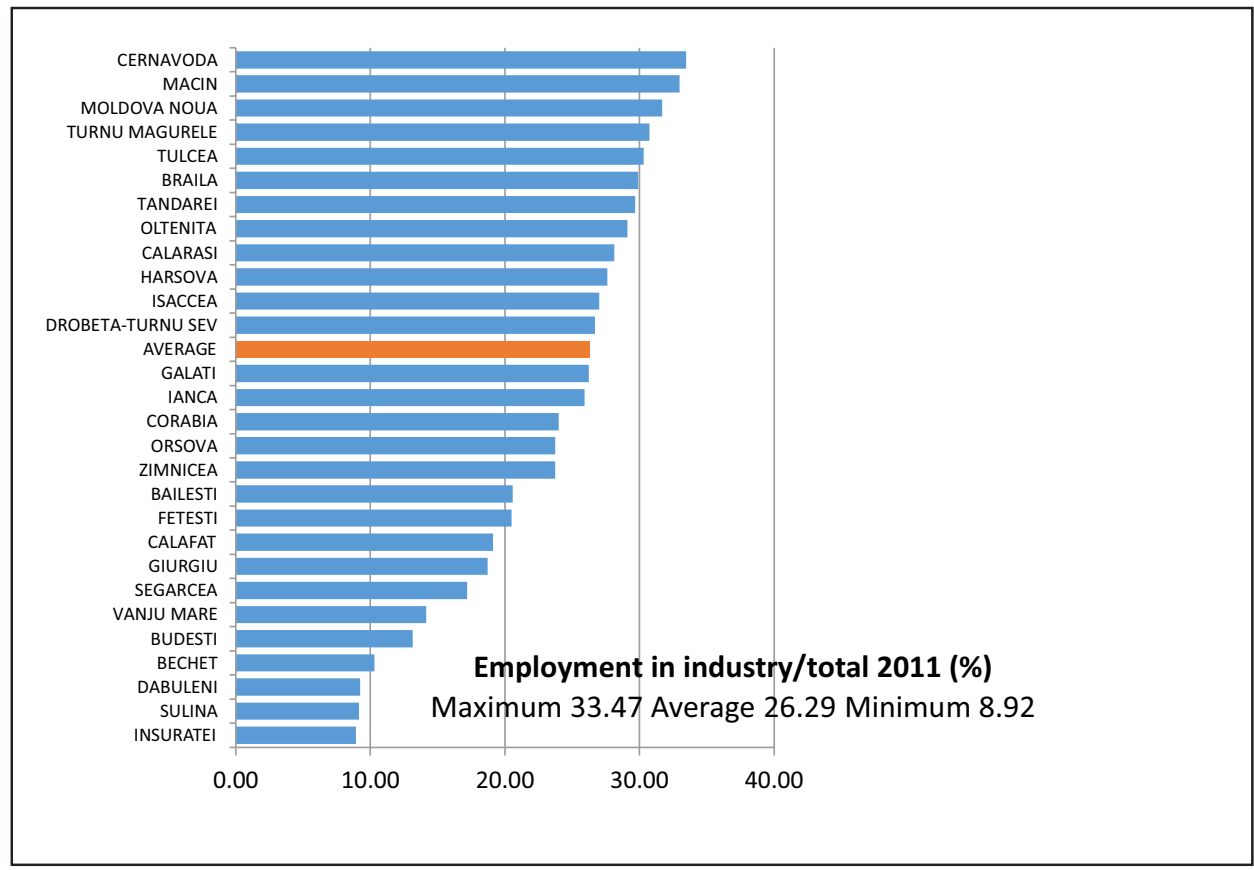

Figure 2. Deindustrialization of the Danube towns in 2011 (c) Source: National Institute of Statistics

industry was redistributed to the slowly growing agricultural and services sectors. The breakdown of the above average industrialized towns shows that some industries have drastically diminished their contribution to the regional employment, while others have resisted better to the changing economic setting.

The industrial decline has continued at a slower pace during the 2000s. A total of 60,000 jobs have been lost by the industrial sector of the region within the context of robust economic growth at the national level and increasing entrepreneurship and FDI in industry. Although there were some important foreign direct investments in the region, raising economic performance and profitability were associated with significant employment contractions. One example is ArcelorMittal Galati where employment has dropped from 36,000 to 6,000 persons along the process of privatization and change of management.

\section{Urban deindustrialization patterns}

The industrial decline has been the driving force of the post-1990 spatial pattern of manufacturing and strongly related to the role of large-scale urban economies. As industrialization has been deeply interwoven in the urban fabric during the socialist period, the highly industrialized regions of the country stood for the highly urbanized as well. Deindustrialization has normalized in many cases the relation between urban scale and functionality by shifting the labor force from manufacturing to services. Regions lagging behind seem to suffer from a uniform employment gap across sectors. This suggests the lack of employment opportunities and attractiveness in these urban regions (Traistaru 
and Wolff, 2003). The Danube Valley Region is one of these underdeveloped regions.

Significant constraints for regional development resulted from deindustrialization. The most striking one refers to the socio-economic polarization of urban centres diminished at all scales: the economic decline of bigger cities reduced their role over adjacent territories and regions, while small and medium-sized towns, especially mono-industrial ones, severely hit by restructuring and cumulative social threats, suffered a loss of urban functions (National Sustainable Development Strategy of Romania. Horizons 2013-2020-2030). The result is represented by a new spatial division of labor in which control functions are concentrated, even more than before, in Bucharest, scientific and technical functions are clustered in the regional cities, and direct production functions while present throughout the country, are agglomerated in particular urban centres.

MNEs locational strategies play a determinant role in shaping the new industrial-spatial structures. Entrepreneurship adds a particular spatial discrimination to the production system mainly because the private sector is averse to lagging behind regions. Regional industrial growth is associated with the support and related industries more than diversity itself, therefore industries located in regions with strong clusters (companies from interrelated industries) record significant increases in creating new companies and jobs. Entrepreneurship in the Danube Region, as measured by the number of new companies is well below the national average, which contributes to increased inter-regional disparities. Additionally, the attractiveness for foreign investments is low, only few Danube towns characterized by stronger Marshallian assets (large labor pool, agglomeration of firms, inter-industrial links) host foreign investments. One third of the Danube counties have contributions under $1 \%$ to any category of exports (Ialomita, Teleorman, Mehedinti, and Giurgiu) (Reindustrialization of Romania: policy and strategy 2010).

Development can be built around key industries. Dominant industries in the Danube towns are either intensive labor-consuming or resource-based, mostly low and medium technology. Metallurgy is one of the industries most affected by deindustrialization: the employment loss was $50 \%$ between 1990 and 2002, and 43\% between 2002 and 2008. Due to the multinational ArcelorMittal Galati, metallurgy is still an important industry for the Danube region.

The intra-regional variation is one of the economic characteristics of the Danube Valley Region as the region still show inherited features from the period prior to 1990 and various pathways taken after 1990 by the Danube towns. Besides, the deindustrialization process took a different pace during the two constitutive periods, in the 1990 and the 2000s (Figure 3 a, b). During the 1990s, below-average industrialized towns have suffered mostly from the changing economic context. Towns with small scale industries have lost their market share and entered a strong process of re-agrarization. The other significant group of towns is represented by those above average industrialized that had a higher resilience to the shock of transition. The 2000s brought about a very different picture, dominated by the decreasing trend of the above average industrialized towns and the increasing trend of below average industrialized towns of the region. This means that industrial towns continue to pass 
manufacturing metallurgical products. In 1991 it was privatized (Sidex Galati, a shared company) and in 2001 the state shares were bought by LNM Holdings NV and in 2006 became ArcelorMittal after Mittal Steel and ArcelorMittal merged. Listed on the 51st rank of Top 100 most valuable companies in Romania, the steelmaker has been experiencing a fall of $30 \%$ of sales revenue since the onset of the financial crisis and a sharp widening of loss. Due to the collapse of steel on the international market, ArcelorMittal Galati currently operates at half of 2008 production level. The company laid off 800 employees between 2012 and 2013. Anyway, the economic and social role of the company is significant: it provides $27 \%$ of the GDP of Galati County and $0.5 \%$ of Romanian GDP; it employs 6,500 persons and supports 50,000 indirect jobs; it has a production capacity of 3 million tons of steel.

The company Saint-Gobain Calarasi, part of French group Saint-Gobain, the world leader in the habitat and construction market, has entered the market in Romania in 2005, the same year laying the cornerstone of the manufacturing plant in Calarasi - the largest greenfield investment after the '90s, our country. The factory was inaugurated in 2007 and so far allocated investment reached approx. 180 million. It has 12 facilities of production in Romania, Calarasi and Tulcea included, which totalize 1100 employees. At Calarasi, thefactory covers an area of 34 hectares, construction of dedicated production lines and offices totaling over 10 hectares and the company has 486 employees, of which 249 are involved in the production process. Production capacity in the factory SaintGobain Glass Building is 21 million square meters of float glass: $40 \%$ of production is directed to partners and projects undertaken in the local market. The remaining $60 \%$ of the products manufactured in Romania go abroad in 42 countries, including Bulgaria, Turkey, Serbia, Ukraine, Moldova, Hungary, Greece and Croatia. Locally, Calarasi glass produced is used in all market segments, but mostly, $50 \%$ is directed to projects in the residential segment.

Construction of the center for processing steel Voestalpine Giurgiu was started in 2010 and was funded jointly by the Fund for European Development Region, the Romanian Government and the Austrian Voestalpine Group.The factory has an annual production capacity that can raise to 130,000 tonnes of sheet processed steel and hired about 50 employees, most recruited from Giurgiu. The Voestalpine Group chose Giurgiu in the south especially because the access to the Danube, but also to regional markets where they can develop their business and can attract new partners and clients. The raw material is brought from Voestalpine steel plant in Linz (Austria), which is also the headquarters of the group, products made in Giurgiu will cover customers in the automotive, electronics, and energy. By opening new production facilities, Voestalpine targets and focuses on the regional markets with Bulgaria, Serbia and Turkey. The Austrian group wish that $70 \%$ of production go to export to clients in the region, and $30 \%$ for clients in Romania.

The ready-mades industry is represented by old companies that have survived through the transition (Braiconf Braila), and by new investments that work for international brands. In Calafat, Maglierie Cristian Impex, Italian firm, hiring about 1,000 employees, produce for Kenzo, Escada, Marc O'Polo, Zara, Massimo Dutti, Lacoste. In Moldova Noua, a former mono-industrial town specialized in mining, hosts the largest employer in the western region, Delphi 


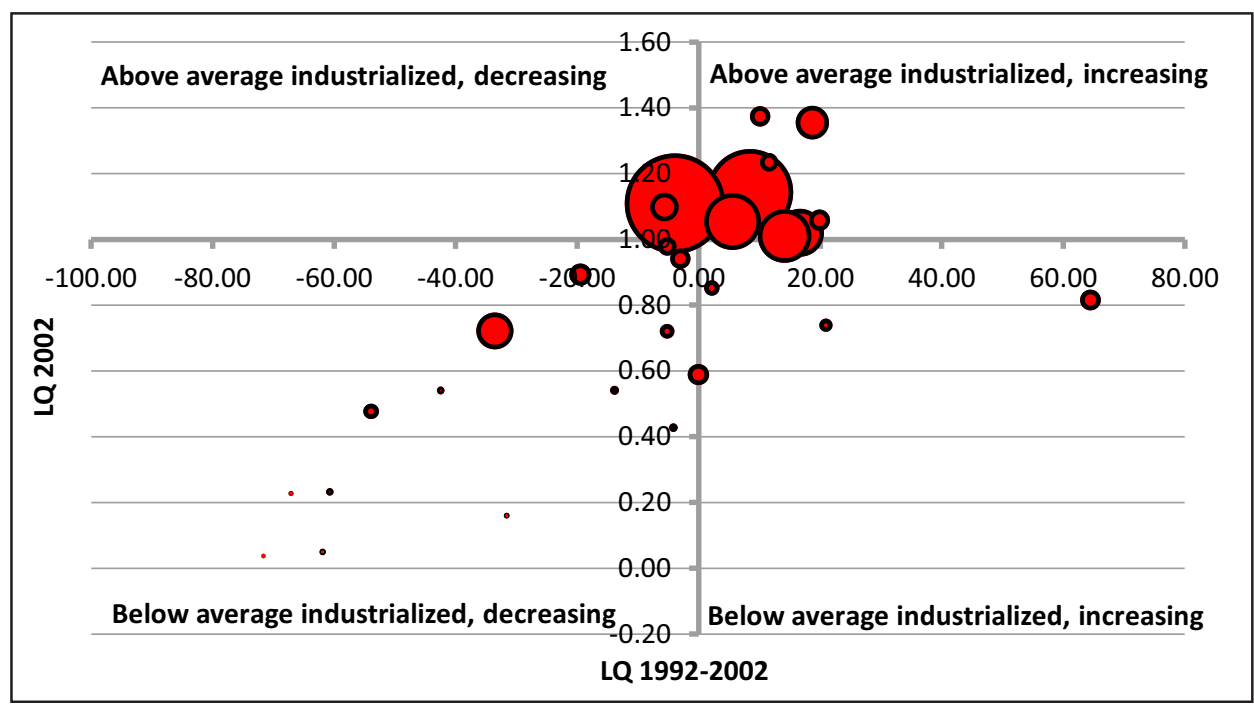

Figure 3. Location Quotient of Manufacturing Employment in the Danube towns, 1992-2002 (a) Source: National Institute of Statistics

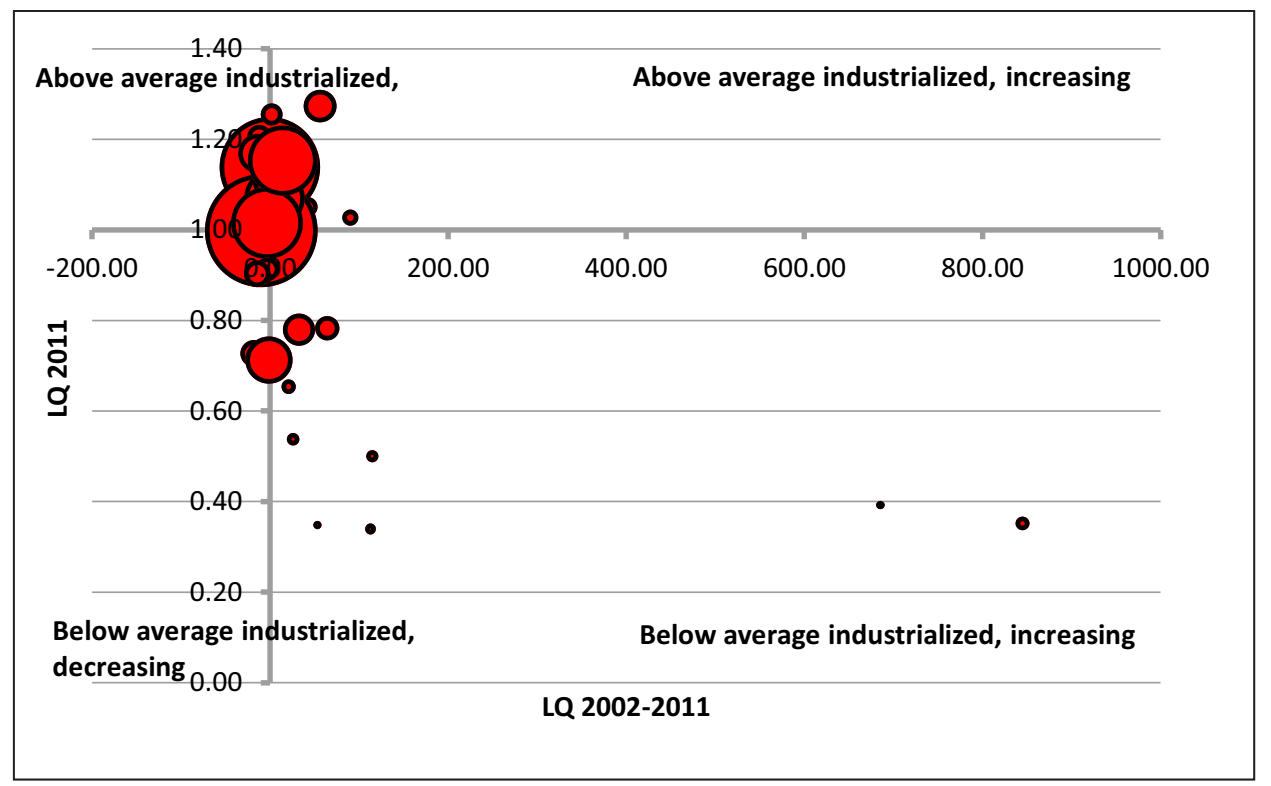

Figure 3. Location Quotient of Manufacturing Employment in the Danube towns, 2002-2011 (b) Source: National Institute of Statistics

through a deindustrialization process, while the agricultural towns start a slow process of reindustrialization. The former, although benefitting from foreign direct investments, could not change the deindustrialization path. The FDI, usually credited with a significant contribution to the growth of local economies, seems to have limited positive effects. Here are some examples of FDI with different effects on the local urban economies. ArcelorMittal Galati SA - is a member of ArcelorMittal, the world's leading steel and mining company. The company started to operate in 1966 as an integrated steel plant and leader in 
Table 1. Patterns of Urban Deindustrialization

\begin{tabular}{lc}
\hline $\begin{array}{l}\text { Location Quotient 2002; \% change over 1992- } \\
2002\end{array}$ & $\begin{array}{c}\text { Location Quotient 2011; \% change over } \\
2002-2011\end{array}$ \\
\hline \multicolumn{3}{c}{ Above average industrialized, decreasing } \\
\hline Galati, Oltenita & $\begin{array}{l}\text { Turnu Magurele, Galati, Braila, Drobeta } \\
\text { Turnu Severin, Moldova Noua }\end{array}$ \\
\hline & Above average industrialized, increasing \\
\hline $\begin{array}{l}\text { Braila, Moldova Noua, Turnu Magurele, Isaccea, Cernavoda, Tulcea, Macin, Oltenita, } \\
\text { Calarasi, Drobeta } \\
\text { Tulcea, Macin }\end{array}$ & \\
\hline
\end{tabular}

Below average industrialized, decreasing

Giurgiu, Isaccea, Bailesti, Vanju Mare, Fetesti, Zimnicea, Corabia, Orsova, Giurgiu, Calafat

Budesti, Dabuleni, Bechet, Sulina, Calafat,

Corabia, Insuratei, Segarcea, lanca, Orsova

Below average industrialized, increasing

Fetesti, Harsova, Tandarei, Cernavoda Vanju Mare, Segarcea, Fetesti, Bailesti,

Budesti, Sulina, Insuratei, Bechet, Dabuleni,

lanca

Note: in italics towns that take the same path of evolution during the whole period

Packard Romania, supplier of car components, associate of the US General Motors Corporation. The company, currently employing 1,200 persons, looks for further business expansion.

\section{Conclusions}

The Danube Region with its agricultural potential and declining industry was structurally affected by inter-sectoral employment shifts which gave birth to a new economic specialization. The region was subject to similar changes with those at the national level, additionally having to cope with the economic peripherability of the region. Restructuring the economy was initially accomplished by shrinking the oversized socialist industrial sector, leading to a counterproductive expansion of the agricultural sector that played the role of a buffer. Small towns, below average industrialized were the first to react to the shock of the transition period loosing largely their industrial employment and, consequently, their capacity to exert urban functions over the neighboring rural areas. Above average industrialized towns followed the same path of evolution but keeping some pockets of resilience for further industrial development. After the first decade of transition, the 2000s were marked by increasing domestic entrepreneurship and FDI location which had positive effects on the local labor markets, although their regional impact on the economy is less marked. Large scale industrial towns continue to display unstable patterns of economic change, while the small towns with dominant agricultural functions show a slow process of industrial growth. Neither the FDI nor the local domestic entrepreneurship could have stopped the process of deindustrialization at the regional level, but they have contributed to shape the new economic regional setting while the Danube appeared to play an increasing role in attracting further investments. 


\section{References}

Dawson, J., (1992), "Peripheral Cities in the European Community: Challenges, Strategies and Prospects", Public Policy and Administration, 7(1), p. 9-20.

Dumitrache, L., Zamfir, D., Nae, M., Simion, G., Storica, I.V., (2016), "The Urban Nexus: Contradictions and Dilemmas of (Post)Communist (Sub)Urbanisation in Romania”, Human Geographies Journal of Studies and Research in Human Geography, 10(1), p. 39-58.

Fujita M. Krugman P. and Venables A., (1999), “The Spatial Economy Cities, Regions and International Trade", MIT Press Cambridge MA.

Goschin, Z., Constantin, D.L., Roman, M., Ileanu, B., (2008), “The Current State and Dynamics of Regional Disparities", Romania Romanian Journal of Regional Science, 2(2), p. 80-105.

Isaic-Maniu, I., (2008), “Territorial Discrepancies concerning SMEs Performances in Romania”, Romanian Journal of Regional Science, 2(1), p. 108-26.

Maniu, M.T., Kallai, E., Popa, D., (2001), "Explaining Growth. Country Report Romania (1990-2000)", GDN website.

Midelfart-Knarvik, K.H., Overman, F.G., Redding, S.J., Venables, A.J., (2000), "The Location of European Industry", Economic Papers 142 Report prepared for the Directorate General for Economic and Financial Affairs, European Commission.

Pavelescu, F.F., (2003), "Rolul industriei si serviciilor in utilizarea capitalului uman" (The role of industry and services in the use of human capital) in Dezvoltarea economica a Romaniei (Economic Development of Romania) Academy Publishing House, Bucuresti p. 487-500.

Popescu, C., (2014), "Deindustrialization and Urban Shrinkage in Romania What Lessons for the Spatial Policy?", Transylvanian Review of Administrative Sciences, 42E/June 2014, p. 181-202.

Sandu, D., (2011), "Disparitati sociale in dezvoltarea si politica regionala din Romania" (Social Disparities in the Regional Development and Policy in Romania), International Review of Social Research, 1, p. 1-30.

Traistaru, I., Nijkamp, P., Longhi, S., (2002), "Regional Specialisation and Concentration of Industrial Activity in Accession Countries", ZEI Working Paper B16, Center for European Integration Studies, University of Bonn.

Traistaru, I., Wolff, G.B., (2003), "Regional Specialization and Employment Dynamics in Transition Countries", Center for European Integration Studies, University of Bonn.

"Orase competitive, Remodelarea geografiei economice a Romaniei" (Competitive Cities Reshaping the Economic Geography of Romania), (2013), World Bank, Romanian Government.

"Strategia Nationala pentru Dezvoltarea Durabila a Romaniei Orizonturi 20132020-2030” (National Sustainable Development Strategy of Romania. 20132020-2030 Horizons), (2008), Romanian Government, UNDP.

"Reindustrializarea Romaniei: Politici si Strategii" (Reindustrialisation of Romania: Policies and Strategies), (2010), Asociatia pentru Studii si Prognoze Economico-Sociale (Association for Economic and Social Studies and Forecast), Bucuresti. 